\title{
The caveolin proteins
}

\section{Terence M Williams ${ }^{* \dagger}$ and Michael P Lisanti*}

Addresses: *Department of Molecular Pharmacology and ${ }^{\dagger}$ The Albert Einstein Cancer Center, Albert Einstein College of Medicine, 1300 Morris Park Avenue, Bronx, NY 10461, USA.

Correspondence: Michael P Lisanti. E-mail: lisanti@aecom.yu.edu

Published: I March 2004

Genome Biology 2004, 5:214

The electronic version of this article is the complete one and can be found online at http://genomebiology.com/2004/5/3/214

(C) 2004 BioMed Central Ltd

\begin{abstract}
Summary
The caveolin gene family has three members in vertebrates: caveolin-I, caveolin-2, and caveolin-3. So far, most caveolin-related research has been conducted in mammals, but the proteins have also been found in other animals, including Xenopus laevis, Fugu rubripes, and Caenorhabditis elegans. Caveolins can serve as protein markers of caveolae ('little caves'), invaginations in the plasma membrane 50-100 nanometers in diameter. Caveolins are found predominantly at the plasma membrane but also in the Golgi, the endoplasmic reticulum, in vesicles, and at cytosolic locations. They are expressed ubiquitously in mammals, but their expression levels vary considerably between tissues. The highest levels of caveolin-I (also called caveolin, Cav-I and VIP2I) are found in terminally-differentiated cell types, such as adipocytes, endothelia, smooth muscle cells, and type I pneumocytes. Caveolin-2 (Cav-2) is colocalized and coexpressed with Cav-I and requires Cav-I for proper membrane targeting; the Cav-2 gene also maps to the same chromosomal region as Cav-l (7q3I.I in humans). Caveolin-3 (Cav-3) has greater protein-sequence similarity to Cav-I than to Cav-2, but it is expressed mainly in muscle cells, including smooth, skeletal, and cardiac myocytes. Caveolins participate in many important cellular processes, including vesicular transport, cholesterol homeostasis, signal transduction, and tumor suppression.
\end{abstract}

\section{Gene organization and evolutionary history}

Research into caveolae began with their morphological identification in 1953. By transmission electron microscopy, they appear as structures resembling 'little caves', which are vesicular invaginations of the plasma membrane of 50-100 nanometers (nm) in size [1]. Caveolin-1 (also known as caveolin, Cav-1 or VIP21) was the first member of the caveolin family to be identified, and it was shown to be a structural component of caveolae and of transport vesicles derived from the transGolgi network $[2,3]$. It was isolated as one of several proteins that became phosphorylated on tyrosine residues in chicken embryo fibroblasts transformed with the $v$-Src oncogene [4]. Monoclonal antibodies directed against Cav- 1 decorated the cytoplasmic protein coat of caveolae, making Cav-1 the first true protein marker of caveolae [2]. Subsequent cloning of the Cav-1 cDNA revealed that it was identical to another protein,
VIP21, which had been cloned almost simultaneously [3,5]. Interestingly, VIP21 was isolated as an integral membrane protein component of transport vesicles derived from the trans-Golgi network in Madin-Darby canine kidney (MDCK) cells, suggesting that Cav-1/VIP21 may have a role in molecular trafficking as well as oncogenesis.

Caveolin-2 (Cav-2) and caveolin-3 (Cav-3) were identified in 1996 using different experimental methods. Cav-2 was discovered by the microsequencing of a $20 \mathrm{kDa}$ protein that copurified with adipocyte-derived caveolar membranes [6]. Further characterization revealed that Cav-2 colocalizes with Cav-1 in caveolae, forms hetero-oligomers with Cav-1, is co-expressed in many of the same cells and tissues, and requires Cav-1 for proper membrane localization [7,8]. Cav-3 (also known as M-caveolin) was identified through 
database searches and traditional cDNA library screening in an attempt to find Cav-1 homologs $[9,10]$.

Caveolin sequences have been obtained from a range of vertebrates, including human, cow, mouse, Xenopus, and Fugu rubripes. A caveolin gene family has also been found in Caenorhabditis elegans [11,12]. The three mammalian genes encoding members of the caveolin family are similar in sequence (Table 1). A phylogenetic tree of all known caveolins shows that the C. elegans Cav-1 sequence is only distantly related to all the others (Figure 1). Interestingly, Cav-1 and Cav-2 are in very close proximity (about 19 kilobases (kb) apart) on human chromosome 7q31.1, while Cav-3 is located on a different chromosome (3p25) [13,14]. Although the evolutionary history of the caveolin genes has not been clearly defined, there are clues within their sequences and genomic organization to suggest possible mechanisms for their origin. For instance, although C. elegans Cav-1 has two exons, the region that is homologous to mammalian caveolins is encoded by only a single exon, suggesting that mammalian caveolins are derived from this particular exon [11]. Also, two observations derived from the human genomic sequence suggest that some family members may have arisen through gene duplication events: firstly, the exonintron boundaries in the last exons of Cav-1, Cav-2, and Cav-3 are in analogous positions; and secondly, exon 2 of Cav-2 is divided into two parts ( $2 \mathrm{a}$ and $2 \mathrm{~b}$ ) by an intron, whereas the two homologous portions in the Cav-1 and Cav-3 sequences are fused together to form the final exon $[13,14]$. This second point may suggest that Cav-2 served as the genomic precursor of Cav-1 and Cav-3.

\section{Characteristic structural features}

Currently, the structural features of this family of proteins are poorly defined, but information gleaned from the protein sequence has enabled some predictions of structure and motifs within the proteins. For instance, all three caveolins have an invariant 'FEDVIAEP' stretch (in the single-letter amino-acid code) within their hydrophilic amino-terminal domains that has come to be termed the 'caveolin signature motif' $[6,9]$. The functional importance of this sequence or motif has yet to be determined, however.

Two Cav-1 isoforms ( $\alpha$ and $\beta$ ) have been identified; the $\beta$ isoform arises from an internal translational start site that gives a shorter amino terminus than that of the $\alpha$ form and is truncated by 31 residues [15]. The predicted domains span almost the same number of residues in all three proteins: the amino-terminal domain comprises the first 101 residues in Cav- $1 \alpha$ and the first 70-86 residues in Cav-1 1 , Cav-2, and Cav-3, with the putative transmembrane domain occupying 33 amino acids and the carboxy-terminal domain containing 43-44 amino acids (Figure 2).

Using a variety of experimental methods, it has been determined that the major sub-cellular location of Cav-1 is at the plasma membrane. From the primary sequence (hydrophilicity plots) and mutational analysis, Cav-1 is predicted to have a membrane-spanning hairpin-like structure, with both amino and carboxyl termini directed towards the cytoplasm (Figure 2). This atypical membrane-spanning model is supported by findings that antibodies directed against the Cav-1 amino or carboxyl terminus require cells to be permeabilized in order to bind Cav-1, that cell-surface biotinylation does not label Cav-1, and that there are known palmitoylation and tyrosine phosphorylation sites within both the amino- and the carboxy-terminal domains of the protein [16-19]; palmitoylation and tyrosine phosphorylation are both cytoplasmically generated post-translational modifications.

Generally speaking, caveolins are small proteins (18-24 kDa). Structurally, however, perhaps one of the most interesting and significant findings about Cav-1 is that it forms an

Table I

\begin{tabular}{|c|c|c|c|c|c|c|c|c|c|c|}
\hline $\begin{array}{l}\text { Human } \\
\text { gene }\end{array}$ & $\begin{array}{l}\text { Chromosomal } \\
\text { location }\end{array}$ & Exon & $\begin{array}{l}\text { Exon } \\
\text { size } \\
\text { (bp) }\end{array}$ & Intron & $\begin{array}{l}\text { Intron } \\
\text { size } \\
(\mathrm{kb})\end{array}$ & $\begin{array}{l}\text { Residues } \\
\text { encoded } \\
\text { by exon }\end{array}$ & $\begin{array}{l}\text { Length of } \\
\text { protein } \\
\text { (amino } \\
\text { acids) }\end{array}$ & $\begin{array}{l}\text { Percentage } \\
\text { similarity } \\
\text { (identity) to } \\
\text { human Cav-I }\end{array}$ & $\begin{array}{l}\text { Percentage } \\
\text { similarity } \\
\text { (identity) to } \\
\text { human Cav-2 }\end{array}$ & $\begin{array}{l}\text { Expression } \\
\text { patterns }\end{array}$ \\
\hline Cav-I & $7 q 31.1$ & $\begin{array}{l}1 \\
2 \\
3\end{array}$ & $\begin{array}{l}30 \\
165 \\
342\end{array}$ & $\begin{array}{l}1 \\
2\end{array}$ & $\begin{array}{l}1.47 \\
31.8\end{array}$ & $\begin{array}{l}1-10 \\
11-65 \\
66-178\end{array}$ & 178 & - & $59(40)$ & $\begin{array}{l}\text { Ubiquitous; highest levels in } \\
\text { adipocytes, endothelia, } \\
\text { smooth muscle cells, and } \\
\text { Type I pneumocytes }\end{array}$ \\
\hline Cav-2 & $7 q 31.1$ & $\begin{array}{c}1 \\
2 \mathrm{a} \\
2 \mathrm{~b}\end{array}$ & $\begin{array}{l}150 \\
188 \\
151\end{array}$ & $\begin{array}{l}1 \\
2\end{array}$ & $\begin{array}{l}0.33 \\
5.76\end{array}$ & $\begin{array}{c}1-50 \\
5|-| \mid 2 \\
113-162\end{array}$ & 162 & $58(38)$ & - & Co-expressed with Cav-I \\
\hline Cav-3 & $3 p 25$ & $\begin{array}{l}1 \\
2\end{array}$ & $\begin{array}{l}114 \\
342\end{array}$ & I & $?$ & $\begin{array}{l}\mid-38 \\
39-15 \mid\end{array}$ & $15 \mid$ & $85(65)$ & $60(39)$ & $\begin{array}{l}\text { Muscle-specific; primarily in } \\
\text { skeletal and cardiac myocytes }\end{array}$ \\
\hline
\end{tabular}

Abbreviations: bp, base pairs; kb, kilobases; ?, unknown. Modified from Razani et al. [42]. 


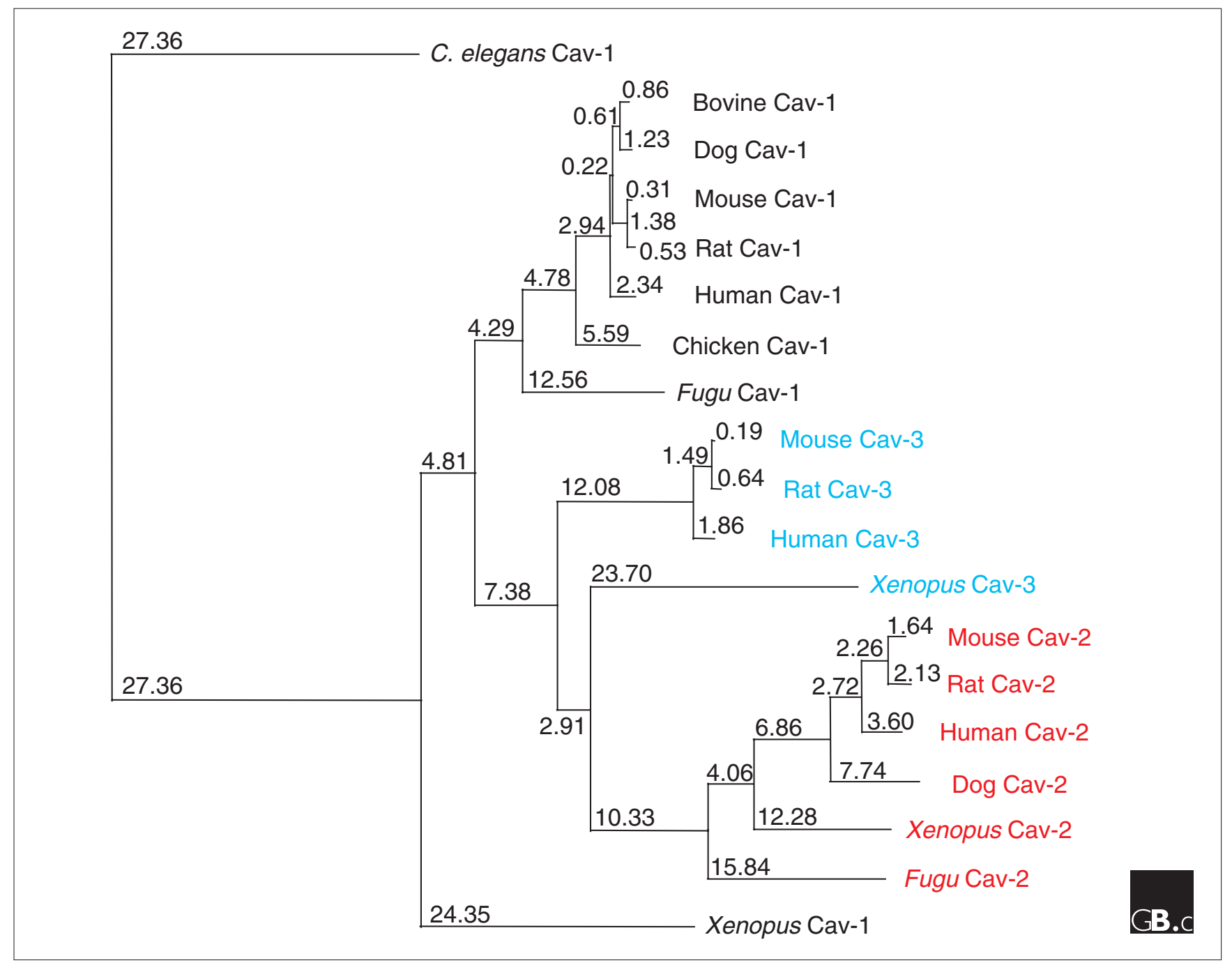

Figure I

A phylogenetic tree depicting the evolutionary relationships of all known caveolin protein sequences. Note that $C$. elegans Cav-2 was not included in this analysis because of its low similarity to the mammalian caveolins. GenBank-derived protein sequences were entered into the ClustalW program to generate a phylogenetic tree using the neighbor-joining method. Numbers indicate horizontal branch lengths, which correspond to the estimated evolutionary distances between the protein sequences.

oligomeric complex comprised of approximately 14-16 monomers, as discovered through velocity gradient ultracentrifugation. In this assay system, Cav-1 was found to migrate as 200-400 kDa complexes [16,20]. Experiments with Cav-1 deletion mutants mapped the oligomerization domain to residues 61-101 [16] (Figure 2). Interestingly, Cav-3 also forms large oligomeric complexes of approximately 350-400 $\mathrm{kDa}$ in vivo, whereas Cav-2 requires Cav-1 to participate in the formation of these high-molecular-mass complexes [7-9].

\section{Localization and function}

Caveolae are considered by many to be a subset of lipid rafts, which are highly-ordered microdomains residing within the plasma membrane that are enriched in certain lipids [21-23]; this may not be completely accurate, however, as some proteins are known to localize selectively to either lipid rafts or caveolae but not both [24]. Caveolaeenriched membrane fractions can be purified efficiently on the basis of their buoyancy and resistance to solubilization by mild non-ionic detergents at $4^{\circ} \mathrm{C}$ [25-30], but other types of membrane microdomains may also be enriched by this kind of purification.

Cav-1 localizes to plasma-membrane caveolae and also to the Golgi apparatus and trans-Golgi-derived transport vesicles [3,5,31]. Cav-1 may have a soluble cytoplasmic form, as well as a secreted form, depending on the cell type [32], and the first 31 amino acids may be important in selectively targeting isoforms of Cav-1 to different cellular compartments [33]. 


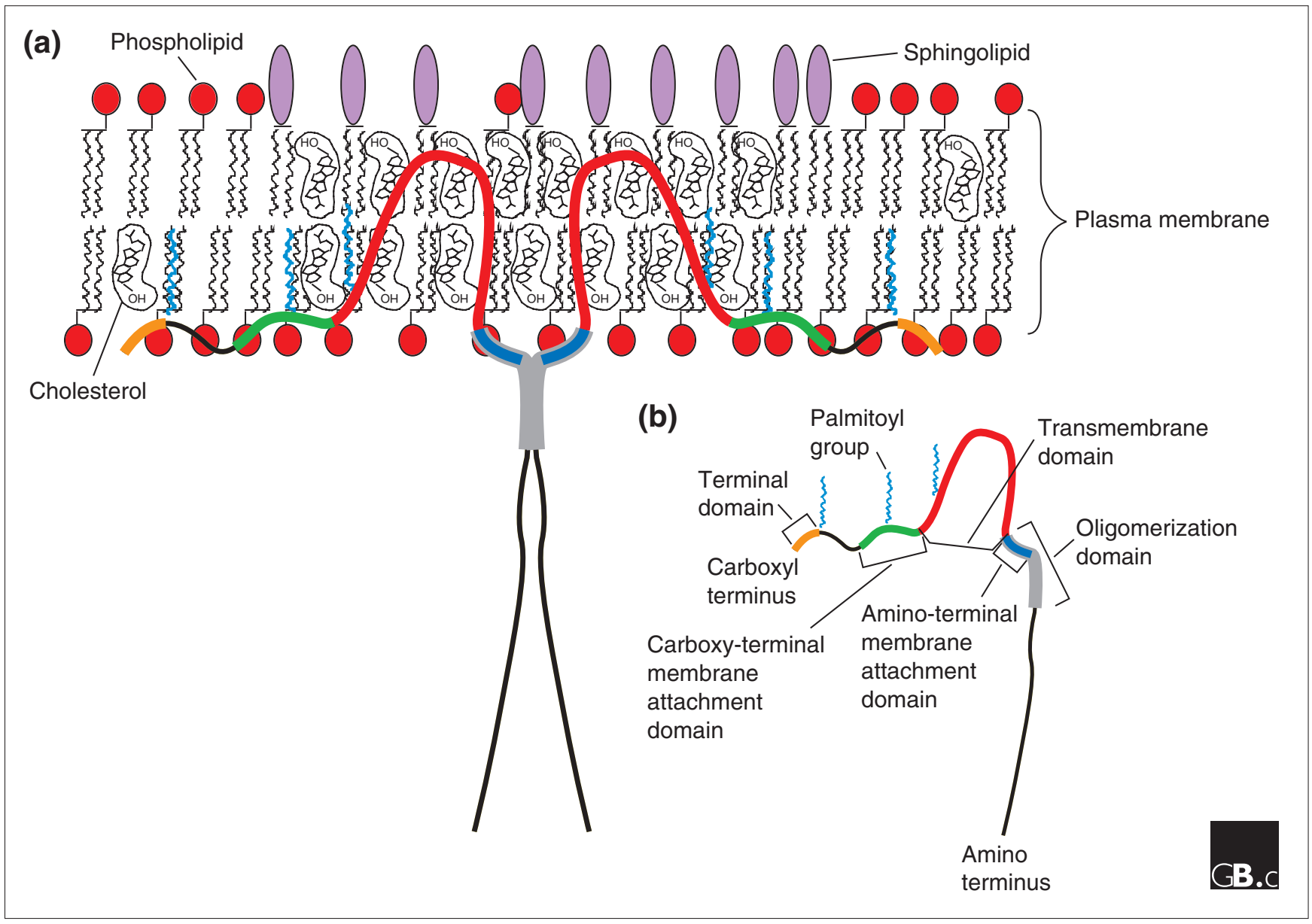

Figure 2

Primary structure and topology of Cav-I. (a) The predicted membrane topology of Cav-I. Two caveolin-I monomers are shown forming a dimer for simplicity, but about 14-16 monomers normally self-associate to form a single caveolin homo-oligomer (the caveolar assembly unit, akin to the clathrin triskelion). Note that both the amino- and carboxy-terminal domains are oriented towards the cytosolic face of the plasma membrane, with a hairpin loop structure inserted within the membrane bilayer. Modified from Razani et al. [42]. (b) The domains present in Cav-I. Note that the amino-terminal membrane-attachment domain is also called the caveolin scaffolding domain (CSD).

Cav-1 is expressed ubiquitously, although at different levels in different tissues, with the highest levels in adipocytes, endothelial cells, fibroblasts, smooth-muscle cells, and a variety of epithelial cells. Cav-2 is tightly co-expressed with Cav-1, whereas Cav-3 is expressed predominantly in striated muscle cells [34]. Interestingly, Cav-1 is required for the proper membrane localization of Cav-2.

Mice deficient in Cav-1, Cav-2, or Cav-3 are viable and fertile, but each has abnormal cellular and tissue-specific phenotypes peculiar to the specific ablated gene [35-43]. A mutant form found in up to $16 \%$ of human breast cancers, Cav-1 (P132L), does not localize properly to the plasma membrane and behaves in a dominant-negative manner, causing the mislocalization and intracellular retention of wild-type Cav1 [44,45]. An analogous P-to-L mutation in Cav-3 (P104L) has been detected in patients with autosomal dominant limb-girdle muscular dystrophy type-1C, and this mutation also behaves in a dominant-negative fashion [46-49]. Wild-type Cav-3 localizes to caveolae and the plasma membrane and also associates with the $\mathrm{T}$ tubules that form from invaginations of the muscle membrane $[50,51]$.

Caveolin-related research has shown that caveolae function in vesicle trafficking [52], cholesterol homeostasis, signal transduction and tumor suppression. Endothelial caveolae may be involved in transcytosis; they have the molecular components used by other transport vesicles during vesicle formation, docking, and fusion [53], and the motor protein dynamin, which is important for vesicle fission, also localizes to caveolae [54,55]. Regarding endocytosis, it appears that certain ligands and extracellular molecules, such as cholera and tetanus toxins, are transported across the plasma membrane through caveolae, rather than via clathrin-dependent mechanisms [56,57]. Pathogens appear to have evolved mechanisms to gain entry into eukaryotic cells through 
caveolae, including simian virus 40 and certain strains of Escherichia coli [58].

Caveolae are enriched with cholesterol and Cav-1 is one of the few proteins that binds cholesterol tightly and specifically $[59,60]$; free cholesterol is required for the proper formation of caveolae [61-63] and regulates the $\mathrm{Cav}-1$ promoter [64]. Intracellular cholesterol balance may be affected by caveolins [65], as a dominant-negative Cav-1 mutant causes intracellular retention of free cholesterol as well as a decrease in cholesterol synthesis and its efflux from the cell [66]. Also, caveolae have been linked to the process of reverse cholesterol transport, during which excess free cholesterol is released into the blood plasma via uptake by highdensity lipoprotein (HDL) particles [67-71], and caveolae appear to be involved in the uptake of cholesterol esters from the plasma.

Caveolae appear to serve as signaling platforms by compartmentalizing and concentrating signaling molecules (this is referred to as the 'caveolae signaling hypothesis') [27]. Various classes of signaling molecules, including G-protein subunits, receptor and non-receptor tyrosine kinases, endothelial nitric oxide synthase (eNOS), and small GTPases [27,42], bind Cav-1 through its 'caveolin-scaffolding domain' (CSD) (Figure 2). Cav-1 also appears to inhibit the downstream activation and signaling of many proteins, including c-Src, H-Ras, mitogen-activated protein (MAP) kinases, and eNOS [72-78]. The evidence that Cav-2 is a signaling modulator is less clear, partly perhaps because its CSD sequence is divergent from that of Cav-1. The Cav-3 CSD is very similar to the Cav-1 CSD, however, and Cav-3-generated caveolae have been shown to compartmentalize and modulate a number of signaling proteins, including eNOS, $\beta$-adrenergic receptors, protein kinase $\mathrm{C}$ isoforms, $\mathrm{G}$ proteins, Src-family kinases, and multiple components of the dystrophin-glycoprotein complex [34,76-79].

Several lines of evidence have implicated Cav-1 in tumor suppression [18,19,80-84], and there is also accumulating evidence that Cav-1 has an anti-proliferative function. Furthermore, the Cav-1 and Cav-2 genes are close to the microsatellite marker $\mathrm{D}_{7} \mathrm{~S}_{52} 2$ on human chromosome 7q31.1 [13,14], a region that is commonly deleted and implicated in the pathogenesis of many human epithelial-based cancers, including breast, colorectal, prostate, ovarian, and renal-cell carcinomas. Recent results [85-90] strongly argue that Cav-1 functions either as a negative regulator of cell proliferation or as a tumor suppressor, in both cultured cells and whole animals.

\section{Frontiers}

The ubiquitous nature and diverse tissue expression of caveolin family members in mammals suggest that caveolins are indeed important for normal cellular and tissue physiology in highly evolved organisms. The discovery of a caveolin gene family in the invertebrate $C$. elegans [11] raises the questions of when caveolins joined the cellular repertoire and whether they are present in more primitive animals, plants or fungi. Another equally important area of research is deciphering the structure of caveolins, as such knowledge would greatly contribute to our understanding of how caveolins function. Recently, gene knockout and transgenic technology has facilitated the study of caveolins in mice, from a whole-organism point of view, allowing the generation of caveolin-deficient or caveolin-overexpressing transgenic mice. The molecular-genetic analysis of these caveolin-deficient mouse models, and cell lines derived from these animals, will greatly facilitate the progress of caveolaerelated research into the next decade.

\section{Acknowledgements}

This work was supported by grants from the National Institutes of Health (NIH), the Muscular Dystrophy Association, the Susan G. Komen Breast Cancer Foundation, and the American Heart Association, as well as a Hirschl/Weil-Caulier Career Scientist Award (all to M.P.L.). T.M.W. was supported by a NIH Medical Scientist Training Grant (T32-GM07288).

\section{References}

I. Palade GE: Fine structure of blood capillaries. J Appl Phys 1953, 24:| $424-1436$.

The first morphological description of caveolae.

2. Rothberg KG, Heuser JE, Donzell WC, Ying YS, Glenney JR, Anderson RG: Caveolin, a protein component of caveolae membrane coats. Cell 1992, 68:673-682.

Identification of caveolin.

3. Kurzchalia TV, Dupree P, Parton RG, Kellner R, Virta H, Lehnert M, Simons K: VIP 2I, A 2 I-kDa membrane protein is an integral component of trans-Golgi-network-derived transport vesicles. J Cell Biol 1992, I I 8:1003-1014.

The initial cloning of VIP2 I/caveolin- I (from dog).

4. Glenney JR Jr, Zokas L: Novel tyrosine kinase substrates from Rous sarcoma virus-transformed cells are present in the membrane skeleton. J Cell Biol 1989, I08:240I-2408.

A paper describing the first caveolin antibodies.

5. Glenney, JR Jr, Soppet D: Sequence and expression of caveolin, a protein component of caveolae plasma membrane domains phosphorylated on tyrosine in Rous sarcoma virustransformed fibroblasts. Proc Natl Acad Sci USA 1992, 89:105I710521 .

The initial cloning and expression of caveolin-I/VIP2 I (from chicken).

6. Scherer PE, Okamoto T, Chun M, Nishimoto I, Lodish HF, Lisanti MP. Identification, sequence and expression of caveolin-2 defines a caveolin gene family. Proc Natl Acad Sci USA 1996, 93: | 3 |-I 35. The cloning of Cav-2.

7. Scherer PE, Lewis RY, Volonte D, Engelman JA, Galbiati F, Couet J, Kohtz DS, van Donselaar E, Peters P, Lisanti MP: Cell-type and tissue-specific expression of caveolin-2. Caveolins I and 2 co-localize and form a stable hetero-oligomeric complex in vivo. J Biol Chem 1997, 272:29337-29346.

Characterization of the interaction of Cav-2 with Cav- I

8. Parolini I, Sargiacomo M, Galbiati F, Rizzo G, Grignani F, Engelman JA, Okamoto T, Ikezu T, Scherer PE, Mora R, et al.: Expression of caveolin-I is required for the transport of caveolin-2 to the plasma membrane. Retention of caveolin-2 at the level of the Golgi complex. J Biol Chem 1999, 274:257I8-25725.

Cav- I is required for proper membrane localization of Cav-2.

9. Tang Z, Scherer PE, Okamoto T, Song K, Chu C, Kohtz DS, Nishimoto I, Lodish HF, Lisanti MP: Molecular cloning of caveolin-3, a novel member of the caveolin gene family expressed predominantly in muscle. J Biol Chem 1996, 27 I:2255-226I.

The cloning and characterization of Cav-3. 
10. Way M, Parton R: M-caveolin: a muscle-specific caveolinrelated protein. FEBS Lett 1995, 376:108-II2.

The cloning and characterization of M-caveolin (Cav-3).

II. Tang Z, Okamoto T, Boontrakulpoontawee P, Katada T, Otsuka A], Lisanti MP: Identification, sequence, and expression of an invertebrate caveolin gene family from the nematode Caenorhabditis elegans: implications for the molecular evolution of mammalian caveolin genes. J Biol Chem 1997, 272:2437-2445. The cloning and expression of caveolins in C. elegans.

12. Scheel J, Srinivasan J, Honnert U, Henske A, Kurzchalia TV: Involvement of caveolin-I in meiotic cell-cycle progression in Caenorhabditis elegans. Nat Cell Biol I999, I:I27-I29.

This paper describes a role for Cav-I in cell division in C. elegans.

13. Engelman JA, Zhang XL, Lisanti MP: Sequence and detailed organization of the human caveolin-I and $\mathbf{- 2}$ genes located near the D7S522 locus (7q3I.I). Methylation of a CpG island in the 5' promoter region of the caveolin-I gene in human breast cancer cell lines. FEBS Lett 1999, 448:221-230.

The genomic organization of human Cav-I and Cav-2.

14. Engelman JA, Zhang XL, Lisanti MP: Genes encoding human caveolin-I and -2 are co-localized to the D7S522 locus (7q3I.I), a known fragile site (FRA7G) that is frequently deleted in human cancers. FEBS Lett 1998, 436:403-4I0.

The chromosomal localization of Cav-I and Cav-2 and their proximity to a site commonly deleted in human cancer.

15. Scherer PE, Tang Z, Chun M, Sargiacomo M, Lodish HF, Lisanti MP: Caveolin isoforms differ in their $\mathbf{N}$-terminal protein sequence and subcellular distribution: identification and epitope mapping of an isoform-specific monoclonal antibody probe. J Biol Chem 1995, 270: 16395-1640I.

The characterization of Cav-I $(\alpha$ and $\beta$ ) isoforms.

16. Sargiacomo M, Scherer PE, Tang Z, Kubler E, Song KS, Sanders MC, Lisanti MP: Oligomeric structure of caveolin: implications for caveolae membrane organization. Proc Natl Acad Sci USA 1995, 92:9407-94II.

This paper describes the oligomeric structure of Cav-I complexes.

17. Dietzen DJ, Hastings WR, Lublin DM: Caveolin is palmitoylated on multiple cysteine residues: palmitoylation is not necessary for localization of caveolin to caveolae. J Biol Chem 1995, 270:68386842.

A description of the palmitoylation of Cav- I.

18. Li S, Seitz R, Lisanti MP: Phosphorylation of caveolin by Src tyrosine kinases: the $\alpha$-isoform of caveolin is selectively phosphorylated by v-Src in vivo. J Biol Chem 1996, 27 I:3863-3868.

This paper describes the phosphorylation of Cav-I by Src tyrosine kinases.

19. Lee $H$, Volonte $D$, Galbiati $F$, lyengar $P$, Lublin DM, Bregman DB, Wilson MT, Campos-Gonzalez R, Bouzahzah B, Pestell RG, et al.: Constitutive and growth factor-regulated phosphorylation of caveolin-I occurs at the same site (Tyr-I4) in vivo: identification of a c-Src/Cav-I/Grb7 signaling cassette. Mol Endocrinol 2000, I 4: I750- I 775 .

A description of the phosphorylation of Cav- I at tyrosine 14

20. Monier S, Parton RG, Vogel F, Behlke J, Henske A, Kurzchalia TV: VIP2 I-caveolin, a membrane protein constituent of the caveolar coat, oligomerizes in vivo and in vitro. Mol Biol Cell 1995, 6:911-927.

A description of oligomeric complexes of Cav- I.

21. Simons K, Toomre D: Lipid rafts and signal transduction. Nat Rev Mol Cell Biol 2000, I:3 I-39.

A review on lipid micro-environments and rafts.

22. Brown DA, London E: Functions of lipid rafts in biological membranes. Annu Rev Cell Dev Biol 1998, I 4: I I I-136.

A review on the functions of lipid rafts.

23. Galbiati F, Razani B, Lisanti MP: Emerging themes in lipid rafts and caveolae. Cell 200I, I06:403-4II.

A review on recent advances in the field of lipid rafts and caveolae.

24. Liu J, Oh P, Horner T, Rogers RA, Schnitzer JE: Organized endothelial cell surface signal transduction in caveolae distinct from glycosylphosphatidylinositol-anchored protein microdomains. J Biol Chem 1997, 272:72I I-7222.

A description of a signaling pathway in caveolae that is distinct from other types of membrane microdomains.

25. Sargiacomo M, Sudol M, Tang Z, Lisanti MP: Signal transducing molecules and glycosyl-phosphatidylinositol-linked proteins form a caveolin-rich insoluble complex in MDCK cells. J Cell Biol 1993, 122:789-807.

The first description of the purification of caveolin-rich membrane domains, and their co-purification with signaling molecules (Src-family kinases and G-proteins).
26. Lisanti MP, Scherer PE, Vidugiriene J, Tang Z, Hermanowski-Vosatka $\mathrm{A}$, Tu YH, Cook RF, Sargiacomo M: Characterization of caveolin-rich membrane domains isolated from an endothelial-rich source: implications for human disease. J Cell Biol 1994, I 26: III-126.

The first detailed proteomic analysis of the protein components of caveolae purified from an endothelial-rich source, lung tissue.

27. Lisanti MP, Scherer PE, Tang Z, Sargiacomo M: Caveolae, caveolin and caveolin-rich membrane domains: a signalling hypothesis. Trends Cell Biol 1994, 4:231-235.

This review proposes the 'Caveolae signaling hypothesis'.

28. Lisanti MP, Tang Z, Scherer PE, Sargiacomo M: Caveolae purification and glycosyl-phosphatidylinositol-linked protein sorting in polarized epithelia. Meth Enzymol 1995, 250:655-668.

A description of the method for purifying caveolae and GPI-linked sorting in epithelial cells.

29. Lisanti MP, Sargiacomo M, Scherer PE: Purification of caveolaederived membrane microdomains containing lipidanchored signaling molecules, such as GPI-anchored proteins, H-Ras, Src- family tyrosine kinases, eNOS, and Gprotein alpha-, beta-, and gamma- subunits. Methods Mol Biol 1999, I 16:51-60.

A description of the enrichment of caveolae complexes containing GPIanchored proteins, H-Ras, Src-family tyrosine kinases, eNOS, and Gprotein subunits.

30. Chang WJ, Ying YS, Rothberg KG, Hooper NM, Turner AJ, Gambliel HA, De Gunzburg J, Mumby SM, Gilman AG, Anderson RG: Purification and characterization of smooth muscle cell caveolae. J Cell Biol 1994, I 26: 127-38.

The isolation and characterization of caveolae from smooth muscle cells.

31. Schlegel A, Lisanti MP: A molecular dissection of caveolin-I membrane attachment and oligomerization. Two separate regions of the caveolin-I carboxy-terminal domain mediate membrane binding and oligomer/oligomer interactions in vivo. J Biol Chem 2000, 275:21605-21617.

A report defining caveolin-caveolin interactions.

32. Liu P, Rudick M, Anderson RG: Multiple functions of caveolin-I. J Biol Chem 2002, 277:4I295-4I298.

A review summarizing the subcellular location and function of Cav- I.

33. Li WP, Liu P, Pilcher BK, Anderson RG: Cell-specific targeting of caveolin-I to caveolae, secretory vesicles, cytoplasm or mitochondria. J Cell Sci 200I, I I 4:I397- I 408.

The isoform-specific targeting of caveolins to different cellular compartments.

34. Song KS, Scherer PE, Tang Z, Okamoto T, Li S, Chafel M, Chu C Kohtz DS, Lisanti MP: Expression of caveolin-3 in skeletal, cardiac, and smooth muscle cells. Caveolin-3 is a component of the sarcolemma and co-fractionates with dystrophin and dystrophin-associated glycoproteins. J Biol Chem 1996, 27I: $15160-15165$.

This paper analyzes the muscle-specific expression pattern of Cav-3.

35. Razani B, Engelman JA, Wang XB, Schubert W, Zhang XL, Marks CB, Macaluso F, Russell RG, Li M, Pestell RG, et al:: Caveolin-I null mice are viable but show evidence of hyperproliferative and vascular abnormalities. J Biol Chem 200I, 276:38I2I-38I38. The generation and characterization of $\mathrm{Cav}-\mathrm{I}^{-1}$ mice.

36. Razani B, Combs TP, Wang XB, Frank PG, Park DS, Russell RG, Li M, Tang B, Jelicks LA, Scherer PE, Lisanti MP: Caveolin-I-deficient mice are lean, resistant to diet-induced obesity, and show hypertriglyceridemia with adipocyte abnormalities. J Biol Chem 2002, 277:8635-8647.

The characterization of adipocyte and triglyceride abnormalities in CavI-deficient mice.

37. Razani B, Wang XB, Engelman JA, Battista M, Lagaud G, Zhang XL, Kneitz B, Hou H Jr, Christ GJ, Edelmann W, Lisanti MP: Caveolin-2deficient mice show evidence of severe pulmonary dysfunction without disruption of caveolae. Mol Cell Biol 2002, 22:2329-2344.

The generation and characterization of $\mathrm{Cav}_{-2} \mathrm{2}^{-1}$ mice.

38. Drab M, Verkade P, Elger M, Kasper M, Lohn M, Lauterbach B, Menne J, Lindschau C, Mende F, Luft FC, et al: Loss of caveolae, vascular dysfunction, and pulmonary defects in caveolingene-disrupted mice. Science 200I, 293:2449-2452. The generation and characterization of $\mathrm{Cav}-\mathrm{I}^{-1}$ mice.

39. Woodman SE, Cheung MW, Tarr M, North AC, Schubert W, Lagaud G, Marks CB, Russell RG, Hassan GS, Factor SM, et al: Urogenital 
alterations in aged male caveolin-I knock-out mice. J Urol 2004, I $71: 950-957$.

This paper describes urogenital abnormalities found in Cav-I-deficient mice.

40. Galbiati F, Engelman JA, Volonte D, Zhang XL, Minetti C, Li M, Hou H Jr, Kneitz B, Edelmann W, Lisanti MP: Caveolin-3 null mice show a loss of caveolae, changes in the microdomain distribution of the dystrophin-glycoprotein complex, and T-tubule abnormalities. J Biol Chem 200I, 276:2 I 425-2I 433.

The generation and characterization of $\mathrm{Cav}^{-3^{-1}}$ mice.

4I. Woodman SE, Park DS, Cohen AW, Cheung MW, Chandra M, Shirani J, Tang B, Jelicks LA, Kitsis RN, Christ G], et al.: Caveolin-3 knock-out mice develop a progressive cardiomyopathy and show hyperactivation of the p42/44 MAPK cascade. J Biol Chem 2002, 277:38988-38997.

This paper describes a progressive cardiomyopathy in Cav-3-deficient mice.

42. Razani B, Woodman SE, Lisanti MP: Caveolae: from cell biology to animal physiology. Pharmacol Rev 2002, 54:43I-467.

A comprehensive review describing caveolins and caveolae.

43. Razani B, Lisanti MP: Caveolin-deficient mice: insights into caveolar function and human disease. I Clin Invest 200I, I08:|553-|56|

A review of the phenotypes of caveolin-deficient mice.

44. Hayashi K, Matsuda S, Machida K, Yamamoto T, Fukuda Y, Nimura $Y$, Hayakawa T, Hamaguchi M: Invasion activating caveolin-I mutation in human scirrhous breast cancers. Cancer Res 200I, 6I:236I-2364.

The first identification of a Cav-I mutation (PI32L) associated with human breast cancer.

45. Lee H, Park DS, Razani B, Russell RG, Pestell RG, Lisanti MP: Caveolin-I mutations (PI32L and null) and the pathogenesis of breast cancer: caveolin-I (PI32L) behaves in a dominantnegative manner and caveolin-I (-I-) null mice show mammary epithelial cell hyperplasia. Am J Pathol 2002, 161:1357-1369.

Molecular characterization of the dominant-negative phenotype of the Cav-I (PI32L) mutant, which is associated with breast cancer.

46. Minetti C, Sotgia F, Bruno C, Scartezzini P, Broda P, Bado M, Masetti E, Mazzocco M, Egeo A, Donati MA, et al:: Mutations in the caveolin-3 gene cause autosomal dominant limb-girdle muscular dystrophy. Nat Genet 1998, 18:365-368.

The first paper to show that Cav-3 mutations cause a novel form of limb-girdle muscular dystrophy.

47. Galbiati F, Volonte D, Minetti C, Chu JB, Lisanti MP: Phenotypic behavior of caveolin-3 mutations that cause autosomal dominant limb girdle muscular dystrophy (LGMD-IC). Retention of LGMD-IC caveolin-3 mutants within the Golgi complex. J Biol Chem 1999, 274:25632-2564I.

The molecular characterization of the behavior of Cav-3 mutants that cause muscular dystrophy.

48. Galbiati F, Volonte D, Minetti C, Bregman DB, Lisanti MP: Limbgirdle muscular dystrophy (LGMD-IC) mutants of caveolin-3 undergo ubiquitination and proteasomal degradation. Treatment with proteasomal inhibitors blocks the dominant negative effect of LGMD-IC mutants and rescues wild-type caveolin-3. J Biol Chem 2000, 275:37702$377 I 1$.

First to show that the LGMD-IC mutants of Cav-3 undergo proteasomal degradation.

49. Galbiati F, Razani B, Lisanti MP: Caveolae and caveolin-3 in muscular dystrophy. Trends Mol Med 200I, 7:435-44I.

A review of Cav-3 and muscular dystrophy.

50. Parton RG, Way M, Zorzi N, Stang E: Caveolin-3 associates with developing T-tubules during muscle differentiation. J Cell Biol 1997, 136:137-154.

Cav-3 associates with the T-tubule system in muscle cells.

5I. Minetti C, Bado M, Broda P, Sotgia F, Bruno C, Galbiati F, Volonte D, Lucania G, Pavan A, Bonilla E, Lisanti MP, Cordone G: Impairment of caveolae formation and T-system disorganization in human muscular dystrophy with caveolin-3 deficiency. Am J Pathol 2002, 160:265-270.

This paper describes caveolae and T-tubule abnormalities in muscular dystrophy in human patients with Cav-3 mutations.

52. Pelkmans L, Helenius A: Endocytosis via caveolae. Traffic 2002, 3:3II-320.

A review of caveolae in endocytosis and transcytosis.
53. Schnitzer JE, Liu J, Oh P: Endothelial caveolae have the molecular transport machinery for vesicle budding, docking, and fusion including VAMP, NSF, SNAP, annexins, and GTPases. J Biol Chem 1995, 270: I 4399-I4404.

The identification of protein components of the vesicle formation, docking and fusion systems in caveolae.

54. Oh P, Mclntosh DP, Schnitzer JE: Dynamin at the neck of caveolae mediates their budding to form transport vesicles by GTP-driven fission from the plasma membrane of endothelium. J Cell Biol 1998, I41:101-II4. A role for dynamin in caveolar vesicle fission.

55. Henley JR, Krueger EW, Oswald BJ, McNiven MA: Dynamin-mediated internalization of caveolae. J Cell Biol 1998, 141:85-99. A role for dynamin in caveolar internalization.

56. Montesano R, Roth J, Robert A, Orci L: Non-coated membrane invaginations are involved in binding and internalization of cholera and tetanus toxins. Nature 1982, 296:65I-653.

The caveolae-mediated transport of cholera and tetanus toxins,

57. Sotgia F, Razani B, Bonuccelli G, Schubert W, Battista M, Lee H, Capozza F, Schubert AL, Minetti C, Buckley JT, Lisanti MP: Intracellular retention of glycosyl-phosphatidylinositol-linked proteins in caveolin-deficient cells. Mol Cell Biol 2002, 22:3905-3926. This paper describes the intracellular retention of glycosylphosphatidylinositol-linked proteins in Cav-1-1- fibroblasts.

58. Norkin LC: Caveolae in the uptake and targeting of infectious agents and secreted toxins. Adv Drug Deliv Rev 200I, 49:30I-315.

A review on the entry of microorganisms via caveolae.

59. Murata M, Peranen J, Schreiner R, Wieland F, Kurzchalia TV, Simons $\mathrm{K}$ : VIP2I/caveolin is a cholesterol-binding protein. Proc Natl Acad Sci USA 1995, 92: 10339-10343.

The first description of the ability of Cav-I to bind cholesterol.

60. Li S, Song KS, Lisanti MP: Expression and characterization of recombinant caveolin: Purification by polyhistidine tagging and cholesterol-dependent incorporation into defined lipid membranes. J Biol Chem 1996, 27 I:568-573.

This paper describes the cholesterol-dependence of incorporation of Cav-I into membranes.

6I. Smart EJ, Anderson RG: Alterations in membrane cholesterol that affect structure and function of caveolae. Methods Enzymol 2002, 353:|31-139.

Describes some biochemical methods for disrupting caveolae.

62. Hailstones D, Sleer LS, Parton RG, Stanley KK: Regulation of caveolin and caveolae by cholesterol in MDCK cells. J Lipid Res 1998, 39:369-79.

The regulation of caveolae formation and caveolin expression by cholesterol.

63. Roy S, Luetterforst R, Harding A, Apolloni A, Etheridge M, Stang E, Rolls B, Hancock JF, Parton RG: Dominant-negative caveolin inhibits H-Ras function by disrupting cholesterol-rich plasma membrane domains. Nat Cell Biol 1999, I:98-105. Cav-I mutants or cholesterol depletion disrupt $\mathrm{H}$-Ras signaling.

64. Bist A, Fielding PE, Fielding CJ: Two sterol regulatory elementlike sequences mediate up-regulation of caveolin gene transcription in response to low-density lipoprotein free cholesterol. Proc Natl Acad Sci USA 1997, 94:10693-10698. The identification of sterol-regulatory elements in the Cav-I promoter.

65. Smart EJ, Ying Y, Donzell WC, Anderson RG: A role for caveolin in transport of cholesterol from endoplasmic reticulum to plasma membrane. J Biol Chem 1996, 27 I:29427-29435. This paper describes the transport of cholesterol by Cav-I.

66. Pol A, Luetterforst R, Lindsay M, Heino S, Ikonen E, Parton RG: A caveolin dominant negative mutant associates with lipid bodies and induces intracellular cholesterol imbalance. J Cell Biol 200I, I 52: 1057-1070.

A caveolin-I mutant can cause intracellular cholesterol imbalances.

67. Fielding PE, Fielding CJ: Plasma membrane caveolae mediate the efflux of cellular free cholesterol. Biochemistry 1995, 34: 14288- I 4292 .

This work implicates caveolae in free cholesterol efflux.

68. Arakawa R, Abe-Dohmae S, Asai M, Ito Jl, Yokoyama S: Involvement of caveolin-I in cholesterol enrichment of high density lipoprotein during its assembly by apolipoprotein and THPI cells. J Lipid Res 2000, 41:1952-1962.

Downregulation of Cav-I reduces cholesterol efflux.

69. Frank PG, Pedraza A, Cohen DE, Lisanti MP: Adenovirus-mediated expression of caveolin-I in mouse liver increases 
plasma high-density lipoprotein levels. Biochemistry 200I, 40:10892-10900.

Upregulation of Cav-I in the liver results in increased plasma HDL cholesterol.

70. Babitt J, Trigatti B, Rigotti A, Smart EJ, Anderson RG, Xu S, Krieger M: Murine SR-BI, a high density lipoprotein receptor that mediates selective lipid uptake, is $\mathbf{N}$-glycosylated and fatty acylated and colocalizes with plasma membrane caveolae. J Biol Chem 1997, 272: I3242-I3249.

Colocalization of SR-BI with caveolae.

7I. Fielding CJ, Fielding PE: Caveolae and intracellular trafficking of cholesterol. Adv Drug Deliv Rev 200I, 49:25I-264.

A review on caveolins and cholesterol trafficking.

72. Li S, Couet J, Lisanti MP: Src tyrosine kinases, G alpha subunits and H-Ras share a common membrane-anchored scaffolding protein, Caveolin. Caveolin binding negatively regulates the auto-activation of Src tyrosine kinases. J Biol Chem 1996, 27I:29182-29190.

Binding and negative regulation of signaling molecules by Cav- I.

73. Couet J, Li S, Okamoto T, Ikezu T, Lisanti MP: Identification of peptide and protein ligands for the caveolin-scaffolding domain. Implications for the interaction of caveolin with caveolae-associated proteins. J Biol Chem 1997, 272:6525-6533. Characterization of protein ligands for the caveolin scaffolding domain.

74. Couet J, Sargiacomo M, Lisanti MP: Interaction of a receptor tyrosine kinase, EGF-R, with caveolins. Caveolin binding negatively regulates tyrosine and serine/threonine kinase activities. J Biol Chem 1997, 272:30429-30438.

Interaction of Cav-I with growth-factor receptors.

75. Huang C, Hepler JR, Chen LT, Gilman AG, Anderson RG, Mumby SM: Organization of $\mathbf{G}$ proteins and adenylyl cyclase at the plasma membrane. Mol Biol Cell 1997, 8:2365-2378.

Partial colocalization of $\mathrm{G}$-protein subunits with caveolae

76. Feron O, Belhassen L, Kobzik L, Smith TW, Kelly RA, Michel T: Endothelial nitric oxide synthase targeting to caveolae. Specific interactions with caveolin isoforms in cardiac myocytes and endothelial cells. J Biol Chem 1996, 27 I:22810-228I4.

This paper describes the localization of eNOS to caveolae in cardiomyocytes.

77. Rybin VO, Xu X, Lisanti MP, Steinberg SF: Differential targeting of beta -adrenergic receptor subtypes and adenylyl cyclase to cardiomyocyte caveolae. A mechanism to functionally regulate the CAMP signaling pathway. J Biol Chem 2000, 275:4|447-4|457.

The localization of $\beta$-adrenergic receptors and adenylyl cyclase to cardiomyocyte caveolae.

78. Rybin VO, Xu X, Steinberg SF: Activated protein kinase $\mathbf{C}$ isoforms target to cardiomyocyte caveolae: stimulation of local protein phosphorylation. Circ Res 1999, 84:980-988.

The localization of protein kinase $C$ isoforms to cardiomyocyte caveolae.

79. Sotgia F, Lee JK, Das K, Bedford M, Petrucci TC, Macioce P, Sargiacomo M, Bricarelli FD, Minetti C, Sudol M, Lisanti MP: Caveolin-3 directly interacts with the carboxy-terminal tail of beta-dystroglycan. Identification of a central WW-like domain within caveolin family members. J Biol Chem 2000, 275:38048-38058.

Interaction of $\mathrm{Cav}-3$ with $\beta$-dystroglycan.

80. Glenney JR Jr: Tyrosine phosphorylation of a 22-kDa protein is correlated with transformation by Rous sarcoma virus. J Biol Chem 1989, 264:20163-20166.

Tyrosine phosphorylation of Cav-l.

8I. Koleske AJ, Baltimore D, and Lisanti MP: Reduction of caveolin and caveolae in oncogenically transformed cells. Proc Natl Acad Sci USA 1995, 92: |38|-| 385.

This paper describes the downregulation of caveolin and caveolae in oncogenically transformed cells.

82. Engelman JA, Wykoff CC, Yasuhara S, Song KS, Okamoto T, Lisanti MP: Recombinant expression of caveolin- $I$ in oncogenically transformed cells abrogates anchorage-independent growth. J Biol Chem 1997, 272:16374-1638I.

Caveolin-I overexpression in oncogene-transformed cells inhibits anchorage-independent growth.

83. Sager R, Sheng S, Anisowicz A, Sotiropoulou G, Zou Z, Stenman G, Swisshelm K, Chen Z, Hendrix MJ, Pemberton P, et al.: RNA genetics of breast cancer: maspin as a paradigm. Cold Spring Harb Sym Quant Biol 1994, 59:537-546.

This paper describes the identification of Cav-I as one of the genes downregulated in human breast-cancer cells.
84. Lee SW, Reimer CL, Oh P, Campbell DB, Schnitzer JE: Tumor cell growth inhibition by caveolin re-expression in human breast cancer cells. Oncogene 1998, 16:|39|-1397.

Cav-I re-expression inhibits cell growth in human breast-cancer cells.

85. Engelman JA, Chu C, Lin A, Jo H, Ikezu T, Okamoto T, Kohtz DS, Lisanti MP: Caveolin-mediated regulation of signaling along the p42/44 MAP kinase cascade in vivo. A role for the caveolin-scaffolding domain. FEBS Lett I998, 428:205-2II. Cav-I inhibits activation of the P42/44 MAP kinase pathway.

86. Galbiati F, Volonte D, Engelman JA, Watanabe G, Burk R, Pestell RG Lisanti MP: Targeted downregulation of caveolin-I is sufficient to drive cell transformation and hyperactivate the p42/44 MAP kinase cascade. EMBO J 1998, 17:6633-6648. Cav-I downregulation results in cellular transformation.

87. Hulit J, Bash T, Fu M, Galbiati F, Albanese C, Sage DR, Schlegel A Zhurinsky J, Shtutman M, Ben-Ze'ev A, Lisanti MP, Pestell RG: The cyclin DI gene is transcriptionally repressed by caveolin-I. J Biol Chem 2000, 275:2I 203-2I 209 Cav-I transcriptionally represses the cyclin DI gene.

88. Williams TM, Cheung MW, Park DS, Razani B, Cohen AW, Muller WJ, Di Vizio D, Chopra NG, Pestell RG, Lisanti MP: Loss of caveolin-I gene expression accelerates the development of dysplastic mammary lesions in tumor-prone transgenic mice. Mol Biol Cell 2003, I 4: 1027-I042.

Cav-I-deficient mice have accelerated development of mammary dysplastic lesions

89. Capozza F, Williams TM, Schubert W, McClain S, Bouzahzah B, Sotgia F, Lisanti MP: Absence of caveolin-I sensitizes mouse skin to carcinogen-induced epidermal hyperplasia and tumor formation. Am J Pathol 2003, 162:2029-2039.

Cav-I-deficient mice are more susceptible to skin carcinogenic treatment.

90. Park DS, Lee H, Frank PG, Razani B, Nguyen AV, Parlow AF, Russell RG, Hulit J, Pestell RG, Lisanti MP: Caveolin-I-deficient mice show accelerated mammary gland development during pregnancy, premature lactation, and hyperactivation of the Jak-2/STAT5a signaling cascade. Mol Biol Cell 2002, I3:34163430.

Caveolin-I-deficient mice have premature lactation and hyperactivation of the p42/44 MAP kinase and STAT5a signaling pathways. 